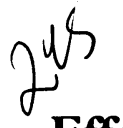

\title{
Effectiveness of programme for reducing cardiovascular risk for men in one general practice $/ \mid$
}

\author{
R L Gibbins, M Riley, P Erimble
}

\begin{abstract}
Objectives-To assess the effectiveness of a programme for reducing cardiovascular risk in men in terms of clinical measurements and perceptions of patients.

Design-Collection of paired data on men attending well person clinics over three to five years. Questionnaire to determine changes in risk related habits.

Setting-Well person clinics in rural general practice with five partners in mid-Wales.

Subjects-The first 687 men seen in the clinic: analysable data obtained on 520 . Initial age range 28-60 years.
\end{abstract}

Main outcome measures-Analysis of serum cholesterol concentration $(\mathrm{mmol} / \mathrm{l})$ and blood pressure (mm Hg). Changes in diet, exercise, smoking, and drinking.

Results-Mean (SD) cholesterol concentration for all subjects increased from $5 \cdot 8(1 \cdot 0)$ to $6 \cdot 0(1 \cdot 0)$, $\mathbf{p}<\mathbf{0 . 0 0 1}$. Overall percentage of ideal weight and mean systolic blood pressure also increased. Mean diastolic blood pressure was unchanged at $84 \mathrm{~mm} \mathrm{Hg}$. Professed dietary change, age, and number of visits all had significant effects on final cholesterol concentration. Those seen more often showed a significant decrease in cholesterol concentrations (in those seen more than twice mean (SD) initial value $6.7(0.9) \mathrm{mmol} / \mathrm{l}$ final value $6.5(1.0) \mathrm{mmol} / \mathrm{h}, \mathrm{p}<0.001)$. Those over 45 years at start of study showed a significant decrease in diastolic blood pressure (mean (SD) initial value 89 (9) $\mathrm{mm} \mathrm{Hg} v$ final value 86 (7) $\mathrm{mm} \mathrm{Hg}, \mathrm{p}<0.001$ ).

Conclusions-These clinics are not effective in achieving a reduction in mean cholesterol concentration or blood pressure, despite evidence that the message of reduction in risk had been successfully transmitted. Success was achieved in older patients and those in whom a definite problem was identified. Identification of high risk groups and clinical case finding with appropriate long term follow up may be more cost effective in reducing cardiovascular risk than non-specific screening of the whole population.

The Surgery, Glandwr Parc,(Builth Wells, Powys) LD2 3DZ

R L Gibbins, general practitioner

M Riley, general practitioner

P Brimble, practice nurse

Correspondence to:

Dr Gibbins.

$B M F$ 1993;306: 1652-6 for the men in our group practice by introducing a mass screening and intervention programme for all men aged 30 to 60 years. A multifactorial approach to risk reduction was adopted, with special emphasis on control of blood pressure and reduction of cholesterol concentrations. The practice is predominantly rural with an annual turnover of patients of about $5 \%$. There are about 7500 patients, of whom about a fifth are over 65 years of age.

The 1990 general practitioners' contract ${ }^{3}$ and current plans for remunerating health promotion activities in primary care have encouraged the development of screening services and well person clinics through the system of health promotion clinics on the unproved assumption that these activities would improve the health of the population. In an attempt to justify this assumption we have reviewed our screening and intervention programme in terms of its measured effect on cholesterol concentration and blood pressure and its perceived effect on the population to which it was applied. The review process was given ethical consideration and approved by representatives of Powys Health Authority and Powys Family Health Services Authority.

\section{Subjects and methods}

Two nurses took part in the initial screening programme. Both were state registered and female. The first $(\mathrm{PB})$ visited the Oxford heart and stroke project to gain experience of screening methods. The protocol was devised after extensive local consultation with clinicians and community staff by $M R$, who also provided additional training in specific techniques for the nurses. The second nurse, who was a trained community nursing sister, was given specific training by $\mathrm{PB}$ and MR. The review process was carried out by PB and another nurse who had by then joined the practice. This nurse had had extensive hospital experience and was trained as an occupational health sister. Both the initial screening programme and the review process were conducted according to standard protocols by all the nurses concerned.

For the initial programme all men aged 28-60 years registered with the practice were invited by letter to visit the surgery for a structured interview and examination. This took place over a two year period. Each patient was allowed 20-25 minutes. The first five minutes were spent explaining the nature of cardiovascular risk factors, why they were relevant to the individual patient, and what we were proposing to do. Questions were invited and answered.

The next 10 to 15 minutes were spent inquiring about the man's risk factors and taking clinical measurements. Family history was taken, then smoking habits, alcohol intake, and dietary and exercise patterns noted. Weight and height were measured and the percentage of the ideal weight calculated from height and weight and reference to standard tables. ${ }^{+}$Blood pressure was measured in a sitting position with a standard desktop mercury sphygmomanometer. A urine sample was obtained when possible and tested for protein and glucose by 
using dipsticks. Venous blood was taken for measurement of non-fasting cholesterol and high density lipoprotein concentrations. The assays were performed at a district hospital laboratory with standard techniques. ${ }^{50}$

The final five to 10 minutes were spent explaining the principles of a healthy lifestyle with particular emphasis on reducing saturated and total fat intake. Patients were given one of several booklets, depending on availability, but care was taken to ensure a consistent message. When positive risk factors relating to obesity, smoking, or alcohol intake had already been identified patients were counselled appropriately. Time was allowed to answer questions and arrangements for follow up discussed when required.

We originally intended to intervene actively for all positive risk factors, but an analysis of the first 100 patients seen showed that over 80 would need recalling if this were done. We therefore limited active secondary intervention to blood pressure and cholesterol concentration unless other definite disease (such as diabetes) was discovered. Table I gives the intervention protocols. The decision as to whether lipid lowering or hypotensive drugs should be prescribed was made clinically by the general practitioner concerned but followed accepted guidelines at the time. ${ }^{7}$

TABLE I-Intervention protocol for screening blood pressure and cholesterol concentration in men

\begin{tabular}{|c|c|}
\hline Value & Action \\
\hline \multicolumn{2}{|c|}{ Blood pressure $(\mathrm{mm} \mathrm{Hg})$ : } \\
\hline$<140 / 90$ & No action \\
\hline$\geqslant 140 / 90$ to & Nurse to repeat within 6 weeks: if $<150 / 100$, annual \\
\hline $\begin{array}{l}<150 / 100 \\
\geqslant 150 / 100\end{array}$ & $\begin{array}{l}\text { review } \\
\text { Refer to general practitioner }\end{array}$ \\
\hline \multicolumn{2}{|c|}{ Cholesterol $(\mathrm{mmol} / \mathrm{l})$ : } \\
\hline$<6 \cdot 0$ & General advice on diet \\
\hline $6 \cdot 0-6 \cdot 5$ & Diet sheet posted with letter giving advice \\
\hline $6 \cdot 6-7 \cdot 7$ & $\begin{array}{l}\text { Recalled for dietary advice, repeat fasting lipids in } 3 \\
\text { months. If still high general practitioner advised }\end{array}$ \\
\hline$>7.8$ & $\begin{array}{l}\text { Recalled within } 6 \text { weeks for fasting lipids, dietary advice, } \\
\text { and consultation with general practitioner }\end{array}$ \\
\hline
\end{tabular}

Boxes 1 and 2 show the letter and dietary advice sent to all patients with an initial cholesterol concentration of $6 \cdot 0-6.5 \mathrm{mmol} / \mathrm{l}$. An information sheet on a standard low cholesterol, low saturated fat, and high fibre diet was given and explained to those with a cholesterol concentration of $6 \cdot 5-7 \cdot 7 \mathrm{mmol} / 1$ at their follow up visit.

\section{Box 1}

\section{Text of letter sent to those with} cholesterol concentration $6 \cdot 0-6 \cdot 5 \mathrm{mmol} / 1$ at first visit

Dear

The tests taken at your recent visit to the screening clinic show that you have a slightly high cholesterol level in your blood. This is no cause for immediate concern, but does mean that you may have a higher risk of developing heart disease later in life. It would therefore be advisable for you to make some changes in your diet by eating:-

\section{Less fatty foods \\ Less dairy produce \\ Less red meat \\ Fewer eggs}

MORE poultry, white fish, fresh fruit and vegetables.

The enclosed leaflet explains this in full.

If you have any queries, please contact me at the surgery.

Yours sincerely

Penny Brimble

Practice screening nurse

\section{Box 2}

Diet sheet sent to those with cholesterol concentration $6 \cdot 0-6 \cdot 5 \mathrm{mmol} / \mathrm{l}$ at first visit

A HEALTHY DIET should include MORE FIBRE and LESS FAT.

This helps to protect against heart disease and certain disorders of the bowel.

FIBRE is the part of cereal and vegetable products that cannot be digested by the body. It is necessary for normal bowel function and to protect against certain bowel disorders.

Ways to eat MORE FIBRE:

1. Eat WHOLEMEAL BREAD instead of white

2. Choose a high fibre breakfast cereal--

eg, WEETABIX, BRANFLAKES, ALL BRAN, WEETAFLAKES

3. Eat some FRESH FRUIT each day

4. Eat VEGETABLES or SALAD each day

5. Eat pastry, cakes, biscuits made with WHOLEMEAL FLOUR rather than white flour

6. NUTS, DRIED FRUIT, PEAS, BEANS LENTILS, WHOLEWHEAT PASTA, BROWN RICE are all good sources of fibre. Try to include them in your diet.

FAT A diet which is high in fat can increase the risk of heart disease.

Ways to eat LESS FAT:

1. AVOID FRIED FOODS

2. AVOID FATTY MEATS - eg sausages, faggots, luncheon meat

3. Cut all the visible fat off meat and eat only the lean

4. Try the LOW FAT DAIRY PRODUCTS that are available--eg, COTTAGE CHEESE, SKIMMED MILK, LOW FAT YOGHURT, LOW FAT SPREADS - eg, St Ivel Gold, Outline

5. REMEMBER that some foods contain a lot of "hidden fat": try to eat less of them--eg, chocolate, cakes, pastry, pies, salad cream, mayonnaise

6. When fat is used in cooking, try to choose one that is POLYUNSATURATED-

Oils: Corn oil, Flora oil, Sunflower oil, Soya oil

Polyunsaturated margarines: Flora, Kraft Polyunsaturated soft margarine, Co-op Goodlife

The first 687 men seen were invited to come for a review in 1991. We had hoped to offer review to all those in the initial survey group of 1006 patients, but time and financial constraints prevented this. At the review interview a similar process to the original interview was used. A similar time allocation was given with an initial explanation of the reasons for the review and an opportunity to ask questions. The same clinical history and measurements were taken. Additionally, changes in smoking, diet, alcohol consumption, and exercise taken were subjectively assessed by a series of direct questions (box 3 ) to determine the patient's view of the effectiveness of the programme. Weight, blood pressure, and serum cholesterol concentration were measured with the same equipment and techniques.

Data were collected initially by using paper records and then transferred to a spreadsheet for analysis. During the transfer all data were checked and those with possible errors of recording or attribution of results excluded from analysis. Means, standard deviations, and $95 \%$ confidence intervals for changes in means have been used when appropriate. The paired $t$ test was used to analyse changes in continuous variables and the McNemar test for changes in proportions. The $\chi^{2}$ test was used for changes in reported fat intake. 


Box 3
Questions on changes in behaviour at
review assessment
Review clinic questionnaire
- SMOKING
Were you a smoker at the time of first interview-
YES or NO (check with recorded data)
Have you changed your smoking habits?-YES or
NO YF YES have you stopped, started, reduced,
IF
increased?
ALCOHOL
How much did you drink at time of first interview?
(check with recorded data and note No of units/
week)
Have you changed your drinking habits?-YES or
NO YIET
IF YES have you stopped, started, reduced,
increased?
- EXERCISE
(check on exercise pattern previously recorded)
Has your exercise pattern changed?-YES or NO
IF YES have you increased or decreased amount of
exercise or NO
IF YES are you eating less fat? eating less carbo-
hydrate? (explain) eating more food generally.
(...)=instructions to interviewing nurse
DIET

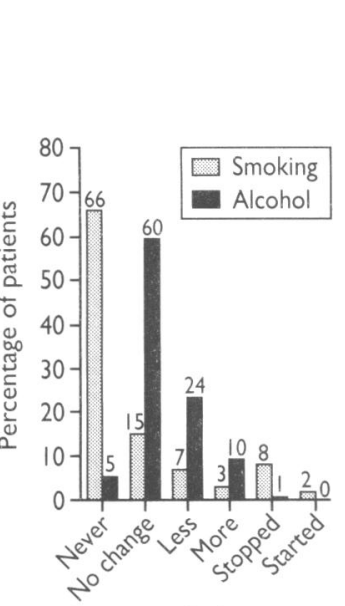

Pattern of behaviour

Change in smoking and alcohol consumption between initial and final visit in men assessed at well man clinic

\section{Results}

\section{INITIAL RESUI.TS}

There were 1565 men aged $28-60$ on the practice agesex register at the start of the screening programme. The initial screening programme is still continuing, but results were analysed in 1988, when 1006 patients had been seen. The response rate at that stage was $72 \%$ Table II gives a summary of age related results for this group.

TABLE II-Mean (SD) values at initial screening for different age groups (data from 1006 patients)

\begin{tabular}{lccccc}
\hline Age & $\begin{array}{c}\text { No of } \\
\text { group }\end{array}$ & $\begin{array}{c}\text { Percentage } \\
\text { ideal body } \\
\text { weight }\end{array}$ & $\begin{array}{c}\text { Systolic } \\
\text { blood } \\
\text { pressure } \\
(\mathrm{mm} \mathrm{Hg})\end{array}$ & $\begin{array}{c}\text { Diastolic } \\
\text { blood } \\
\text { pressure } \\
(\mathrm{mm} \mathrm{Hg})\end{array}$ & $\begin{array}{c}\text { Serum } \\
\text { cholesterol } \\
\text { concentration } \\
(\mathrm{mmol} / \mathrm{l})\end{array}$ \\
\hline$<30$ & 6 & $111(15)$ & $135(5)$ & $82(8)$ & $4 \cdot 8(1 \cdot 6)$ \\
$30-39$ & 307 & $112(14)$ & $127(15)$ & $81(10)$ & $5 \cdot 6(1 \cdot 1)$ \\
$40-49$ & 345 & $114(14)$ & $133(16)$ & $84(10)$ & $6 \cdot 0(1 \cdot 1)$ \\
$50-60$ & 314 & $116(15)$ & $142(20)$ & $92(11)$ & $6 \cdot 2(1 \cdot 1)$ \\
$>60$ & 34 & $114(19)$ & $151(20)$ & $92(13)$ & $6 \cdot 5(1 \cdot 1)$ \\
Total & 1006 & $114(15)$ & $134(18)$ & $86(11)$ & $6 \cdot 0(1 \cdot 2)$ \\
\hline
\end{tabular}

TABLE: III-Initial screening results for different groups

\begin{tabular}{|c|c|c|c|}
\hline & $\begin{array}{l}\text { Initial } \\
\text { group }\end{array}$ & $\begin{array}{l}\text { Group } \\
\text { attending for } \\
\text { recall }\end{array}$ & $\begin{array}{l}\text { Group not } \\
\text { attending for } \\
\text { recall }\end{array}$ \\
\hline No in group & 1006 & 520 & 167 \\
\hline Mean (SD) percentage ideal body weight & $114(15)$ & $114(14)$ & $115(15)$ \\
\hline Mean (SD) systolic blood pressure ( $\mathrm{mm} \mathrm{Hg}$ ) & $134(18)$ & $132(17)$ & $132(18)$ \\
\hline Mean (SD) diastolic blood pressure ( $\mathrm{mm} \mathrm{Hg}$ ) & $86(11)$ & $84(10)$ & $84(10)$ \\
\hline Mean (SD) serum cholesterol concentration $(\mathrm{mmol} / \mathrm{l})$ & $6 \cdot 0(1 \cdot 2)$ & $5 \cdot 8(1 \cdot 0)$ & $6 \cdot 0(1.5)$ \\
\hline
\end{tabular}

TABI.E IV-Percentage of patients at selected intervention levels at initial and final visits

\begin{tabular}{|c|c|c|c|c|c|}
\hline \multirow[b]{2}{*}{ Intervention factor } & \multicolumn{2}{|c|}{$\begin{array}{c}\text { Proportion (\%) of } \\
\text { patients exceeding at }\end{array}$} & \multirow[b]{2}{*}{$\begin{array}{c}\text { SE of } \\
\text { difference }\end{array}$} & \multirow{2}{*}{$\begin{array}{l}95 \% \text { Confidence } \\
\text { intervals for } \\
\text { difference }\end{array}$} & \multirow{2}{*}{$\begin{array}{l}\text { p Value on } \\
\text { McNemar } \\
\text { test }\end{array}$} \\
\hline & $\begin{array}{l}\text { Initial } \\
\text { visit }\end{array}$ & $\begin{array}{l}\text { Final } \\
\text { visit }\end{array}$ & & & \\
\hline Serum cholesterol $>6.5 \mathrm{mmol} / \mathrm{l}$ & 21.5 & $24 \cdot 6$ & 1.99 & $-0 \cdot 80-1.99$ & $0 \cdot 149$ \\
\hline Systolic blood pressure $>150 \mathrm{~mm} \mathrm{Hg}$ & $9 \cdot 0$ & $9 \cdot 0$ & 1.35 & $-2 \cdot 27-2 \cdot 67$ & $1 \cdot 0$ \\
\hline Diastolic blood pressure $>90 \mathrm{~mm} \mathrm{Hg}$ & $18 \cdot 5$ & $9 \cdot 0$ & 1.79 & $5 \cdot 73-12 \cdot 73$ & $<0.0001$ \\
\hline
\end{tabular}

A total of 280 patients had an initial cholesterol concentration of over $6.5 \mathrm{mmol} / \mathrm{l}$. Of these, $55 \mathrm{had}$ values over $7.8 \mathrm{mmol} / \mathrm{l}$. After a minimum of six months on lipid lowering diets 47 of these still had values over $7.8 \mathrm{mmol} / \mathrm{l}$. There were 133 patients with a systolic blood pressure over $150 \mathrm{~mm} \mathrm{Hg}, 21$ of whom had values over $180 \mathrm{~mm} \mathrm{Hg}$. Two hundred and thirty five patients had a diastolic blood pressure over $90 \mathrm{~mm} \mathrm{Hg}$, of whom 55 had values over $100 \mathrm{~mm} \mathrm{Hg}$.

Two patients had previously unidentified noninsulin dependent diabetes. The practice already had an ascertainment rate for diabetes of over $2 \%$. No other chronic diseases were identified.

REVIEW RESUITS

Out of 687 invited patients 526 were seen for review. This represented $33.6 \%$ of the men aged $28-60$ years on the practice age-sex register. Data from six patients were excluded because they were incomplete or possible errors were noted on cross checking, leaving analysable data on 520 . This group had a mean (SD) initial age of $43.2(8.6)$ years and had been on average first seen 3.9 years ago. A total of 201 patients were under 39 years of age, $16640-49$ years of age, and 153 50-59 years of age at the time of review. Table III provides a comparison of the initial screening results for the 1006 patients seen initially, the 520 attending for review, and the 167 patients who were invited for review but did not attend.

A number of patients (384) were seen only for the initial and final reviews; 136 received further intervention, usually because of high cholesterol concentrations. Of these, 100 were seen three times, 26 four times, four five times, three six times, and one each seven, eight, and nine times. These visits were specifically for the follow up of problems identified during the screening process and did not include other consultations with a general practitioner.

At the time of final review the elapsed time since their first visit was two years in two patients, three years in 156, four years in 266, and five years in 96 patients.

The figure shows reported changes in smoking and alcohol consumption. Note that $125(24 \%)$ patients claimed to be drinking less and $78(15 \%)$ to have reduced or stopped smoking.

Overall, 409 patients reported no change in their exercise pattern; 62 were taking more and 49 less exercise. Two hundred and seventy eight men reported no dietary change; 216 said they were eating less fat and 19 less carbohydrate. Seven said they were generally eating more food than at the initial assessment.

Table IV shows changes in percentages of patients above selected intervention levels for cholesterol concentration and blood pressure at initial and final visits. The increase seen in percentage of patients with cholesterol concentrations over $6.5 \mathrm{mmol} / \mathrm{l}$ was not significant, but there was a significant fall in the percentage of patients with a diastolic blood pressure greater than $90 \mathrm{~mm} \mathrm{Hg}(\mathrm{p}<0.0001)$.

Various drug treatments were used during the study to lower cholesterol concentration in selected patients. Of the 520 patients for whom data were available at follow up, 112 had an initial concentration of over $6.5 \mathrm{mmol} / \mathrm{l}$. Ten of these were being treated with simvastatin; all had initial concentrations of over $7.0 \mathrm{mmol} / 1$ except one $(6.8 \mathrm{mmol} / 1)$.

Of the 520 patients, 252 had a systolic pressure of $140 \mathrm{~mm} \mathrm{Hg}$ or over or a diastolic pressure of $90 \mathrm{~mm} \mathrm{Hg}$ or over, or both at initial screening. Twenty nine of these patients were taking hypotensive agents at review: 13 were taking $\beta$ blockers, 10 diuretics, four calcium antagonists, three angiotensin converting enzyme inhibitors, and two other drugs. Three were on multiple treatments. 


\begin{tabular}{|c|c|c|c|c|c|}
\hline Item & $\begin{array}{c}\text { Mean } \\
(\mathrm{SD}) \text { at } \\
\text { initial visit }\end{array}$ & $\begin{array}{l}\text { Mean (SD) } \\
\text { at final visit }\end{array}$ & $\begin{array}{c}\text { Mean (SD) } \\
\text { of change }\end{array}$ & $\begin{array}{l}95 \% \text { Confidence } \\
\text { interval for } \\
\text { change }\end{array}$ & $\begin{array}{l}\text { p Value for } \\
\text { paired } t \\
\text { test }\end{array}$ \\
\hline Percentage ideal body weight & $113 \cdot 8(13 \cdot 7)$ & $115 \cdot 4(14 \cdot 1)$ & $1.56(5.9)$ & 1.05 to 2.06 & $<0.001$ \\
\hline Systolic blood pressure $(\mathrm{mm} \mathrm{Hg})$ & $132(17)$ & $134(16)$ & $1 \cdot 70(14 \cdot 6)$ & 0.44 to 2.96 & 0.008 \\
\hline Diastolic blood pressure $(\mathrm{mm} \mathrm{Hg})$ & $84(10)$ & $84(8)$ & $-0.66(8.9)$ & -1.44 to 0.11 & 0.094 \\
\hline $\begin{array}{l}\text { Serum high density lipoprotein } \\
(\mathrm{mmo} / 1)\end{array}$ & $1 \cdot 19(0 \cdot 31)$ & $1.23(0.47)$ & $0.45(0.4)$ & 0.01 to 0.08 & $<0.001$ \\
\hline Serum cholesterol $(\mathrm{mmol} / \mathrm{l})$ & $5 \cdot 8(1 \cdot 0)$ & $6 \cdot 0(1 \cdot 0)$ & $0.21(0.9)$ & 0.13 to 0.28 & $<0.001$ \\
\hline
\end{tabular}

TABLE VI-Effect of age, diet change, and number of visits on serum cholesterol concentration (mmoll) (data on 520 patients)

\begin{tabular}{|c|c|c|c|c|}
\hline Classification & $\begin{array}{c}\text { Mean (SD) at } \\
\text { initial visit }\end{array}$ & $\begin{array}{c}\text { Mean (SD) at } \\
\text { final visit }\end{array}$ & $\begin{array}{l}\text { Mean (SD) of } \\
\text { change }\end{array}$ & $\begin{array}{l}95 \% \text { Confidence } \\
\text { interval for } \\
\text { change }\end{array}$ \\
\hline Whole group $(n=520)$ & $5 \cdot 8(1 \cdot 0)$ & $6 \cdot 0(1 \cdot 0)$ & $-0.021(0.9)$ & 0.13 to 0.28 \\
\hline No diet change $(n=278)$ & $5 \cdot 5(0 \cdot 9)$ & $5 \cdot 8(1 \cdot 0)$ & $0.36(0.8)$ & 0.27 to 0.45 \\
\hline Less fat $(n=216)$ & $6 \cdot 2(1 \cdot 0)$ & $6 \cdot 2(1 \cdot 0)$ & $-0.004(1.0)$ & -0.13 to 0.12 \\
\hline Initial age $<45$ years $(n=289)$ & $5 \cdot 6(1 \cdot 0)$ & $6 \cdot 0(1 \cdot 0)$ & $0 \cdot 44(0 \cdot 7)$ & 0.36 to 0.52 \\
\hline Initial age $\geqslant 45$ years $(n=231)$ & $6 \cdot 0(1 \cdot 0)$ & $5 \cdot 9(1 \cdot 0)$ & $-0.08(0.9)$ & -0.20 to 0.04 \\
\hline Seen twice only $(n=384)$ & $5 \cdot 4(0 \cdot 8)$ & $5 \cdot 8(0 \cdot 9)$ & $0.36(0 \cdot 8)$ & 0.28 to 0.43 \\
\hline Seen more than twice $(n=136)$ & $6.7(0.9)$ & $6.5(1.0)$ & $-0 \cdot 20(1 \cdot 0)$ & -0.38 to -0.03 \\
\hline
\end{tabular}

Table $\mathrm{V}$ gives the initial and final results of proportion of ideal body weight, blood pressure, and high density lipoprotein and cholesterol concentrations for the whole group of 520 men. Significant increases over the study period are shown for all the variables except diastolic blood pressure.

Tables VI and VII give further analyses of cholesterol concentrations and blood pressure. They show changes in subgroups determined by age, change in dietary habits, and those who were seen more than twice and therefore had more active intervention. Results for subgroups are compared with the whole group results.

Table VIII gives details of the results of a two sample $t$ test on the effect of reported dietary change, age, and number of visits on serum cholesterol concentration and blood pressure. All three factors had a significant effect on cholesterol concentration, with lack of diet change and a young initial age producing a rise and more than two visits a fall in final values. For blood pressure the only significant influence was age, with an older starting age resulting in a significant fall.

Other variables which might have influenced the observed changes were analysed. The group with a reported reduced fat intake were seen more often (mean (SD) $2.6(1.0)$ times) than those without any diet change $(2 \cdot 2(0 \cdot 6)$ times $)$, but there was no difference in the time since or age at first visit.

More of the men initially over 45 years of age claimed to have reduced their fat intake than those under 45 years at first visit $(129(44 \cdot 5 \%) v 90(39 \cdot 1 \%))$ but this was not significant $\left(\chi^{2}, p>0.02\right)$. The older group were first seen more recently (mean (SD) $3.4(0 \cdot 5) v 4 \cdot 2(0 \cdot 6)$ years) and tended to be seen more often $(2.5(0.9) v 2.3$ $(0.6)$ visits).

The group who were seen more than twice and who therefore had active secondary intervention gave the highest proportion of all with a reported reduced fat intake $(95,70 \%)$. This was significantly greater than in those seen only twice $\left(\chi^{2}, p<0.001\right)$ when only 121
$(31.5 \%)$ claimed a reduced fat intake. They were also older than those seen only twice (mean (SD) 45.3 (8.5) $v 42.6(8.3)$ years), but there was little difference in the time since first visit $(3.7(0.8) v 3.9(0.7)$ years $)$.

\section{Discussion}

Apart from a slightly higher diastolic blood pressure in the 50-59 year age group there were no differences in our initial results from those found in a larger Welsh population. ${ }^{8}$ Comparison with the OXCHECK study9 shows a lower percentage of subjects with cholesterol concentrations over 6.5 and $8.0 \mathrm{mmol} / \mathrm{l}$, but this might be explained by assay differences, differing age distribution of the sample, and similar factors.

We have not included in our results any correction factors for the increase in age of the sample between the first and final measurements. Both cholesterol concentration and blood pressure increase with age.

TABLE VIII-Effect of diet, age, and number of visits on serum cholesterol concentration and blood pressure. $p$ Values for 2 sample $t$ test

\begin{tabular}{llcc}
\hline $\begin{array}{l}\text { Factor } \\
\text { (subgroups compared) }\end{array}$ & $\begin{array}{l}\text { Diet (no } \\
\text { change } v \\
\text { less fat) }\end{array}$ & $\begin{array}{c}\text { Age } \\
(<45 v \geqslant 45 \\
\text { years })\end{array}$ & $\begin{array}{c}\text { No of } \\
\text { visits } \\
(2 v>2)\end{array}$ \\
\hline $\begin{array}{l}\text { Cholesterol } \\
\text { Systolic blood pressure }\end{array}$ & $\begin{array}{l}\mathrm{p}<0.001 \\
\mathrm{p}=0.415\end{array}$ & $\begin{array}{l}\mathrm{p}<0.001 \\
\mathrm{p}=0.27\end{array}$ & $\begin{array}{l}\mathrm{p}<0.001 \\
\mathrm{p}=0.27\end{array}$ \\
$\begin{array}{l}\mathrm{p}=0.45 \\
\text { Diastolic blood pressure }\end{array}$ & $\mathrm{p}<0.001$ & $\mathrm{p}=0.021$ \\
\hline
\end{tabular}

Cholesterol concentration seems to plateau above the age of 40 years, ${ }^{81011}$ but blood pressure continues to rise with age. ${ }^{812}$ These trends were observed in our initial results (see table II). Regression analysis data provided by Heartbeat Wales (personal communication) for age and sex related cholesterol concentration and blood pressure assume a linear relation between age and cholesterol concentration, which may be inadvisable in view of other data. ${ }^{8}{ }^{10-12}$ It seems reasonable therefore to use the initial age related results of our sample as standards for comparison, though it is accepted that this limits the value of any statistical analysis. The value of blood pressure readings taken in an ordinary clinical setting with a normal (not random zero) sphygmomanometer might also be questioned. There were probably some minor variations of technique in both this and interviewing methods, but these are difficult to exclude in routine practice. This analysis is of a functioning clinical system rather than a theoretical model, and though exclusion of normal practices might make the results more precise, they would be less applicable to practical primary care.

If these limitations are accepted our programme of risk screening and assessment coupled with advice on risk reduction had no beneficial effect on cholesterol concentration or blood pressure for the total group. This is despite a perceived reduction in dietary fat intake, which suggests that the risk message did have an impact when delivered initially. This was supported by discussions with local retailers. There was an eightfold increase in sales of skimmed and semiskimmed milk during the study period, increased sales of wholemeal bread, and reduced sales of fatty meat,

TABLE VII-Effect of age, diet change, and number of visits on blood pressure (data from 520 patients). Figures are systolic/diastolic blood pressure $(\mathrm{mm} \mathrm{Hg})$

\begin{tabular}{lccrr}
\hline Classification & $\begin{array}{c}\text { Mean }(\mathrm{SD}) \text { at initial } \\
\text { visit }\end{array}$ & $\begin{array}{c}\text { Mean (SD) at } \\
\text { final visit }\end{array}$ & $\begin{array}{c}\text { Mean (SD) of } \\
\text { change }\end{array}$ & $\begin{array}{c}95 \% \text { Confidence interval } \\
\text { for change }\end{array}$ \\
\hline Whole group $(\mathrm{n}=520)$ & $132(17) / 84(10)$ & $134(16) / 84(8)$ & $1 \cdot 70(14 \cdot 6) /-0 \cdot 66(8 \cdot 9)$ & $0 \cdot 44$ to $2 \cdot 96 /-1 \cdot 44$ to $0 \cdot 11$ \\
No diet change $(\mathrm{n}=278)$ & $131(17) / 84(10)$ & $133(17) / 83(8)$ & $2 \cdot 08(16 \cdot 6) /-0 \cdot 58(9 \cdot 0)$ & $0 \cdot 12$ to $4 \cdot 04 /-1 \cdot 64$ to $0 \cdot 48$ \\
Less fat in diet $(\mathrm{n}=216)$ & $134(17) / 86(11)$ & $135(14) / 85(8)$ & $1 \cdot 03(12 \cdot 1) /-1 \cdot 19(8 \cdot 8)$ & $-0 \cdot 60$ to $2 \cdot 65 /-2 \cdot 37$ to $-0 \cdot 01$ \\
Initial age $<45$ years $(\mathrm{n}=289)$ & $128(16) / 81(9)$ & $130(13) / 82(9)$ & $2 \cdot 35(13 \cdot 1) / 1 \cdot 75(8 \cdot 3)$ & $0 \cdot 83$ to $3 \cdot 86 / 0 \cdot 79$ to $2 \cdot 71$ \\
Initial age $\geqslant 45$ years $(\mathrm{n}=231)$ & $137(17) / 89(9)$ & $138(19) / 86(7)$ & $0 \cdot 89(16 \cdot 3) /-3 \cdot 67(8 \cdot 8)$ & $-1 \cdot 23$ to $3 \cdot 00 /-4 \cdot 80$ to $-2 \cdot 53$ \\
Seen twice only $(\mathrm{n}=384)$ & $130(16) / 83(10)$ & $132(16) / 83(8)$ & $2 \cdot 03(15 \cdot 4) /-1 \cdot 22(8 \cdot 9)$ & $0 \cdot 48$ to $3 \cdot 57 /-1 \cdot 01$ to $0 \cdot 77$ \\
Seen more than twice $(\mathrm{n}=136)$ & $139(18) / 89(10)$ & $139(16) / 86(8)$ & $0 \cdot 77(12 \cdot 3) /-2 \cdot 16(8 \cdot 8)$ & $-1 \cdot 31$ to $2 \cdot 85 /-3 \cdot 66$ to $-0 \cdot 67$ \\
& & & & \\
\hline
\end{tabular}


together with an increased health awareness in food purchases generally.

We were not aware of any general adverse effects of the screening programme. The risks of producing unnecessary anxieties related to health in patients were discussed when the original programme was set up. We agreed that the best way to minimise these was by careful explanation of our aims and by not raising expectations for treatment which we could not fulfill. This was one of the principle reasons for concentrating our efforts on lipid reduction and management of hypertension.

The general consultation rate of patients did not increase during the study. The recorded number of visits does not include other consultations. No restriction was placed on doctors or nurses in discussing problems related to risk during routine consultations if it was felt to be clinically appropriate.

Our subgroup results, however, conflict with the results for the whole group and suggests that active intervention for both high blood pressure and high cholesterol concentration may produce important benefit. This is deduced from the fact that patients seen more often, who by definition had an identified problem, showed a significant decrease in cholesterol concentration (see tables VI and VIII) and that there was a reduction in the number of patients above the intervention level for diastolic blood pressure (see table IV). The fact that there was no significant increase in cholesterol concentration in those who claimed a reduced fat intake is also encouraging. Unfortunately the benefit obtained by these groups is negated for the group as a whole by the complete lack of benefit for those seen only twice and for the younger patients, who theoretically might benefit most.

We calculated that the initial screening visit and associated procedures cost $£ 12$ per patient. This includes both clinical and administrative time and cost of laboratory tests and assumes that the programme is run largely by non-medical staff. If doctors were to run the clinics costs would be considerably higher. The total cost for a well person clinic of this type in a practice of 10000 patients with about 4500 eligible patients based on a rolling programme of five yearly review would therefore be about $£ 11000$ a year. Drug costs for treatment of previously unidentified hyperlipidaemia and hypertension have not been included in this figure nor have the costs of long term follow up of identified problems.

Population screening and intervention for cardiovascular risks is time consuming' and expensive. For it to be cost effective a reduction in risk for the general population must be shown. Unfortunately, we have not found any such reduction, and there is no published evidence from the United Kingdom to contradict our findings. Our results also suggest that it may be more worth while to find and treat those with established problems rather than screening the population as a whole. It has already been shown that case finding is an effective way of identifying the at risk population for hypertension. ${ }^{13}$ This may mean that the current emphasis on well person screening clinics in primary care is misplaced and that effort should be redirected to detecting those with actual abnormalities and treating them properly.

Both the medical profession and the government must be sure that the use of limited medical resources for population screening of any sort is justifiable when including these activities in the remuneration system for general practitioners. Our results suggest that this is not yet proved and more comprehensive studies are needed.

This project was supported by grants from Powys Health Authority and Powys Family Health Services Authority and would not have been possible without the full support of the staff and patients of the Builth and Llanwrtyd Wells group practice.

1 Welsh Heart Programme Directorate. The pulse of Wales: preliminary report of the Welsh health heart survey 1985. Cardiff: Welsh Heart Programme, 1986. (Heart Beat Report No 4.)

2 Parish R, Catford J. Breathing life into Wales: progress in the Welsh hear programme. Health Trends 1987;19:23-7.

Department of Health. Terms of service for doctors in general practice. London: Department of Health, 1989.

4 Metropolitan Life Insurance Company. Statistical bulletin No 40. New York: Metropolitan Life Insurance Company, 1959.

5 Richmond W. Preparation and properties of a cholesterol oxidase from nocardia and its application to the enzymatic assay of total cholesterol in serum. Clin Chem 1973;19:1350-6.

6 Burstein M, Scholnick HR, Morfin RJ. Rapid method for the isolation of lipoprotein from human serum by precipitation with polyanions. Lipid Research 1970;19:583.

7 Shepherd J, Betteridge DJ, Durrington P, Laker M, Lewis B, Mann J, et al. Strategies for reducing coronary heart disease and desirable limits for blood lipid concentrations: guidelines of the British Hyperlipidaemia Association. BM7 1987;295:1245-6.

8 Heart of Wales. Cardiff: Health Promotion Authority for Wales, 1986.

9 Imperial Cancer Research Fund OXCHECK Study Group. Prevalence of risk factors for heart disease in OXCHECK trial: implications for screening in primary care. $B M 7$ 1991;302:1057-60.

$10 \mathrm{~K}$ witerovich P, ed. The fohns Hopkins complete guide for avoiding heart disease: beyond cholesterol. Baltimore: John Hopkins University Press, 1989:293.

11 Mann J, Lewis B, Shepherd J, Winder AF, Fenster S, Rose L, et al. Blood lipid concentrations and other cardiovascular risk factors: distribution, prevalence, and detection in Britain. BMF 1988;296:1702-6.

12 Lenther C, ed. Geigy tables. 7th ed. Basle: Ciba Geigy, 1970:553.

13 Holmen J, Forsen L, Hiort PF, Midthjell K, Waaler HT, Bjerndal A. Detecting hypertension: Screening versus case finding in Norway. $B M$ 1991;302:219-22.

(Accepted 15 April 1993)

\section{SOUND BITES}

\section{The fellowship examination-a patient's view}

"We would be grateful if you could help us out with the fellowship examinations," said a letter from the hospital department where I am a frequent attender. Two weeks later four of us assembled on the ward. The examinees were already lining up apprehensively outside the ward door.

None of the patients had met before but at the end of three hours we were intimate with each other's diagnosis, investigations, and treatment. We had hardly made ourselves comfortable when a bell rang and the first candidate appeared flanked by two examiners. I started to mark each candidate on presentation, knowledge of diagnosis, investigations, and treatment. I was so used to being on inteview panels it had become second nature.

The setting and time allowed for each candidate was not conducive to good rapport but the differences between candidates were marked. Some of them did not greet us or look us in the eye. Time did not allow for any discussion on the difficulties the condition had caused us, the most important element for us.

As the morning progressed the time for each candidate seemed to get shorter and shorter. It was getting more and more difficult to do what the candidate wanted, in my case to try to shut my eye, frown, whistle, and raise my eyebrows. Between the candidates we shook our heads, nodded, or made a brief comment about the candidate's performance.

Over coffee at the end of it all we tallied up our scores. I had passed four, awarded one distinction, and failed six. The examiners had disappeared. Would their assessments be the same as ours? We shall never know but with the emphasis on consumers in the citizen's charter can we expect a patient's representative on the examiner's panel in the future?-VALERIE LOBBAN, Edinburgh

We are delighted to receive submissions of up to 600 words on $A$ paper (or patient) that changed my practice, $A$ memorable patient, The one message I would like to leave behind, or similar topics. 